\title{
Chagas disease in Mexico
}

\author{
Julieta Rojo-Medina, ${ }^{1}$ Cuitláhuac Ruiz-Matus, ${ }^{2}$ Paz María Salazar-Schettino ${ }^{3}$ and \\ Jesús Felipe González-Roldán ${ }^{4}$
}

${ }^{1}$ Secretaría de Salud, National Center of Blood Transfusion, Directorate General, Ciudad de México, Mexico; '2Secretaría de Salud, Directorate General of Epidemiology, Ciudad de México, Mexico; ${ }^{3}$ Universidad Nacional Autónoma de México, Faculty of Medicine, Department of Microbiology and Parasitology; Ciudad de México, Mexico; ${ }^{4}$ Secretaría de Salud, National Center of Preventive Programs and Disease Control, Directorate General, Ciudad de México, Mexico

\begin{abstract}
Chagas disease, which is caused by Trypanosoma cruzi, is considered to be the most serious parasitic disease in America. It is transmitted mainly by triatominae ("kissing bugs"). Mazzoti reported the first two human cases in Mexico. The form of transmission is by parasites entering the organism in feces of the insect, by blood transfusion, from mother to child, by organ transplant and laboratory accidents. In Mexico, 1.1 million people are estimated to be infected; the incidence in 2012 was 0.70 per 1,00,000 population. In 2017, the highest incidence rates were registered in Yucatán, Oaxaca and Hidalgo. The infection causes cardiomyopathies and mega-organs of the digestive tract. Diagnosis in the acute phase is by parasitological approach and, in the chronic phase, by laboratory screening studies. In Mexico's blood banks, screening for Chagas disease is mandatory; from 2007 to 2016, seroprevalence has decreased from 0.40 to 0.32 due to the improvement of donor selection processes and the ad hoc questionnaire. The targets of the parasite are neurons and smooth and myocardial muscle cells. The association of neuronal and smooth muscle destruction defines the presentation of chagas mega-syndromes. Initial manifestations of the disease can go unnoticed; 5\% show apparent signs and symptoms and 30\% will progress to the chronic asymptomatic phase. Currently available treatments have effect in the acute phase. For the control of Chagas disease, the Specific Action Program for the Prevention and Control of Chagas Disease (PAE Chagas 2013-2018) is available to initiate activities aimed at eliminating transfusion and congenital transmission and controlling vector transmission. The success of medical care depends on oportune detection, early etiological treatment and coverage broadening. On the other hand, monitoring and screening of pregnant women living in risk areas and blood and organ donors universal screening will enable the elimination congenital and transfusion transmission.
\end{abstract}

KEY WORDS: Chagas disease. Trypanosoma cruzi. Triatominae.

\section{Chagas disease epidemiological panorama in Mexico}

American trypanosomiasis or Chagas disease is considered the most serious parasitosis in America and is one of the 14 diseases of poverty on the World Health Organization list. ${ }^{1}$

In 1909, Carlos Ribeiro Justiniano Chagas identified the parasite for the first time; he described the insects that transmit the disease and delved into some symptoms, including cardiac and nervous system alterations.
Originally, Carlos Chagas named the causative parasite of this disease Schizotrypanum cruzi. ${ }^{2}$

In 1928, Hoffman managed to correlate triatomine for the first time as Chagas vector and, in 1940, Dr. Luis Mazzoti reported the first two human cases in Mexico. ${ }^{3}$

American trypanosomiasis or Chagas disease is caused by the protozoan parasite Trypanosoma cruzi. The infection is transmitted mainly by triatomines of the Reduviidae family, Hemiptera order ("kissing bugs"), Triatominae subfamily. It is mainly transmitted by contact with infected feces or urine of triatomine insects
Date of reception: 24-07-2018

Date of acceptance: 25-07-2018

DOI://dx.doi.org/10.24875/GMM.M18000196
Gac Med Mex. 2018;154:513-519

Contents available at PubMed www.gacetamedicademexico.com 


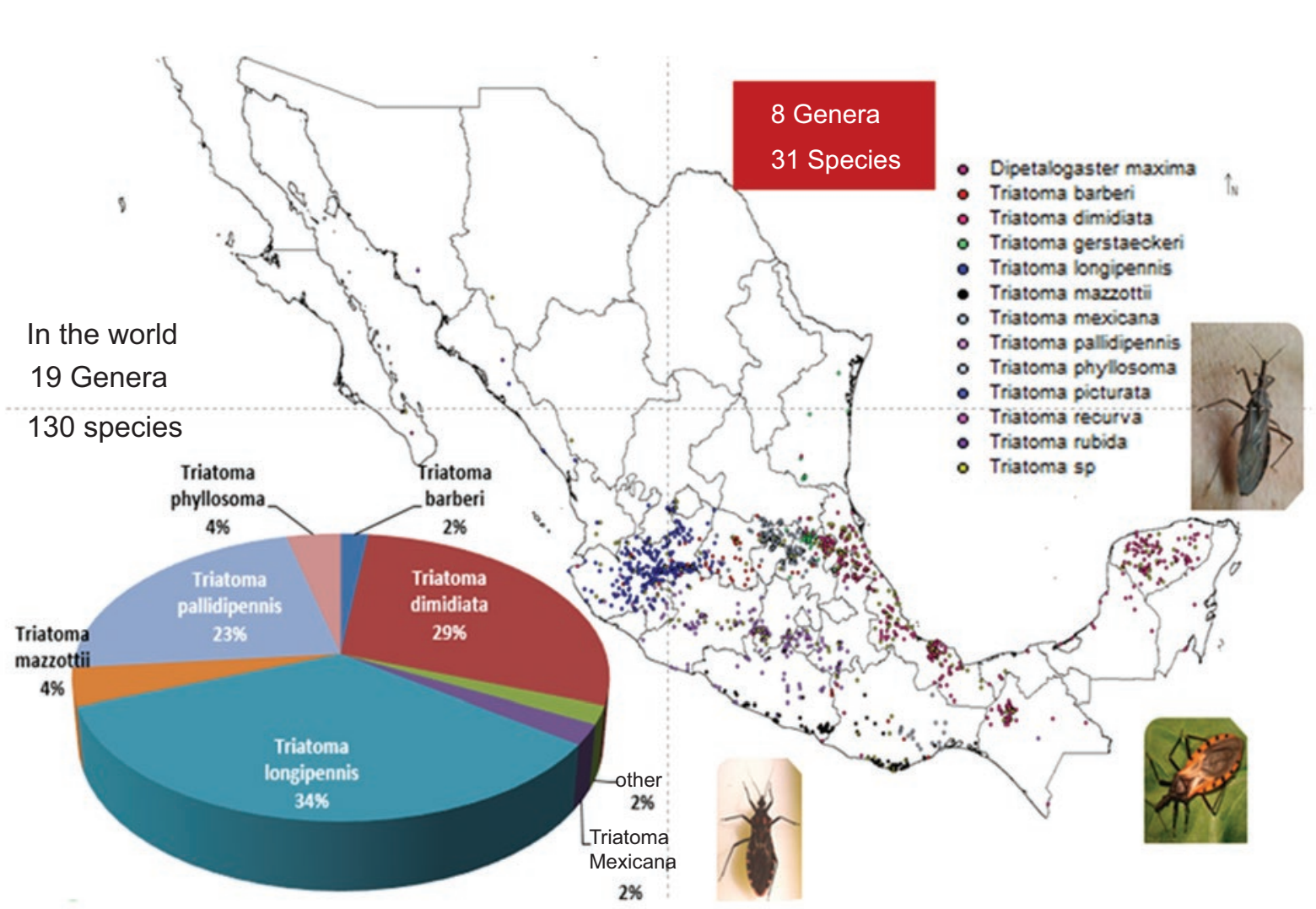

Figure 1. Triatomine bugs distribution in Mexico, 2015. Source: Sistema Único de Información para la Vigilancia Epidemiológica, Secretaría de Salud.

that feed on blood. These insects live in cracks and holes of houses walls and roofs in rural and suburban areas. They remain hidden during the day and at night they become active, bite in an exposed area of the skin and defecate near the bite. The parasites penetrate the body when the person scratches and pushes the feces or urine towards the bite, the eyes, mouth or some open skin lesion. There are other forms of transmission: by consumption of food contaminated by $T$. cruzi, blood transfusion, from infected mother to child, organ transplant and by laboratory accidents. ${ }^{4}$

This condition is mainly distributed in Latin America, but in the last decades, it has been observed in the United States, Canada, in 17 European countries and some of the Western Pacific. In Mexico, eradication of Rhodnius prolixus as the main vector was achieved between 2009 and 2010. Twenty percent of the Latin American population is considered to be at risk for acquiring the infection, especially in endemic areas of countries of the region. ${ }^{5}$

In Mexico, it is considered a public health problem, since 1.1 million people are estimated to be infected. ${ }^{6}$ The incidence from 2000 to 2007 remained within a range of 0.07 to 0.37 per 100 thousand population; as of 2008, it increased from 0.61 to 0.70 per 100 thousand population in 2012 .
In 2015, through the National System of the Ministry of Health, 8 genera and 31 species of triatoma were detected in Mexico. In two third parts of the Mexican territory there are conditions for vector transmission to take place.

The intra-domiciliary species are Triatoma barberi, associated with cardiomyopathies and "megas (dilatations) of digestive tract organs, and Triatoma dimidiata, distributed from the Andean countries and Central America up to Mexico, associated with heart disease. The main species identified in 2015 in the Mexican Republic were Triatoma longipenmis (34\%), Triatoma pallidipennis (23\%) and Triatoma dimidiata (29\%) (Fig. 1).

The Directorate General of Epidemiology of the Ministry of Health performs, through the National System of Epidemiological Surveillance, the monitoring of acute and chronic trypanosomiasis, which is to be reported immediately.

The report of cases shows an upward trend until 2015, due to the registration of 53 retroactive cases originating in the State of Mexico. During 2018, until April, 150 cases were recorded throughout the Republic.

Of the reported cases, the most affected population is the group aged from 45 to 49 years. When compared by gender, in 2007 there was a ratio of 2.9 males 
Table 1. Acquisition and handling of clinical samples for Chagas disease diagnosis

\begin{tabular}{|c|c|c|c|c|c|c|}
\hline \multicolumn{2}{|c|}{ Type of sample Method } & Medium/container/shipping form & Time & Technique & & \\
\hline \multicolumn{5}{|c|}{ A. Parasitoscopic techniques } & \multicolumn{2}{|l|}{$\stackrel{\infty}{-}$} \\
\hline Capillary blood & Digital puncture & $\begin{array}{l}\text { Extended on slide, if possible stained with } \\
\text { Giemsa, blood sample on slide for TA detection }\end{array}$ & $\begin{array}{l}\text { During the acute phase of } \\
\text { disease }\end{array}$ & Thick smea & $a r$ & \\
\hline Whole blood & $\begin{array}{l}\text { Venipuncture in tubes } \\
\text { with heparin/EDTA }\end{array}$ & $2 \mathrm{~mL}$, shipping with coolers at 4 to $8^{\circ} \mathrm{C}$ & $\begin{array}{l}\text { During the acute phase of } \\
\text { disease }\end{array}$ & Thick smea & $\operatorname{ar} \frac{\bar{C}}{\frac{\sigma}{\varrho}}$ & \\
\hline Whole blood & $\begin{array}{l}\text { Venipuncture in tubes } \\
\text { with heparin/EDTA }\end{array}$ & $2 \mathrm{~mL}$, shipping with coolers at 4 to $8^{\circ} \mathrm{C}$ & $\begin{array}{l}\text { During the acute phase of } \\
\text { disease }\end{array}$ & $\begin{array}{l}\text { Fluorescen } \\
\text { micro-heme }\end{array}$ & atocr & \\
\hline Whole blood & $\begin{array}{l}\text { Venipuncture in tubes } \\
\text { with heparin }\end{array}$ & 3 to $5 \mathrm{~mL}$, shipping with coolers at 4 to $8^{\circ} \mathrm{C}$ & $\begin{array}{l}\text { During the acute phase of } \\
\text { disease }\end{array}$ & Blood cultu & dre & \\
\hline Whole blood & $\begin{array}{l}\text { Venipuncture in tubes } \\
\text { with heparin }\end{array}$ & $2 \mathrm{~mL}$, shipping with coolers at 4 to $8^{\circ} \mathrm{C}$ & $\begin{array}{l}\text { During the acute phase of } \\
\text { disease }\end{array}$ & Inoculation & $\frac{\bar{c}}{\mathrm{inm}}$ & nouse \\
\hline \multicolumn{5}{|c|}{ B. Immunoserological techniques } & 4 & \\
\hline Serum & $\begin{array}{l}\text { Venipuncture in tubes } \\
\text { with anticoagulants }\end{array}$ & $1 \mathrm{~mL}$, shipping with coolers at 4 to $8^{\circ} \mathrm{C}$ & $\begin{array}{l}\text { During the late acute and } \\
\text { chronic phase of disease }\end{array}$ & & $\frac{\frac{c}{0}}{n}$ & \\
\hline
\end{tabular}

Source: Lineamientos para la vigilancia epidemiológica de Chagas por laboratorio. Reference 7.

per each female and by 2017 the ratio decreased: 2.1 cases in males for each female.

For 2017, the highest incidence rates in the country were recorded in Yucatán (4.0), Oaxaca (2.4) and Hidalgo (2.1). The national incidence rate was 0.7 per 100000 population. The state of Guerrero had the highest rate of new cases at acute phase. At its chronic phase, cases were recorded almost in all states, except for Baja California, Guerrero and Querétaro. The highest rate (3.96) was observed in Yucatan.

In 2018, the states with the highest incidence rates are Yucatán (0.8), Quintana Roo (0.8) and Nayarit (0.7). The mortality rate in 2016 was 0.02 for males and 0.01 for females.

For the diagnosis of this infection, serological techniques were developed using own antigenic preparations and indirect immunofluorescence techniques, established as reference methodologies.

For laboratory diagnosis, studies in the acute phase focus on the search and recognition of T. cruzi in blood (parasitological approach), since at initial stages of the disease important parasitemias are found. At the chronic phase (asymptomatic or symptomatic) parasitemias are transient and therefore the diagnosis is fundamentally established by searching for circulating antibodies against T. cruzi (serological approach) ${ }^{6}$ (Table 1).

Experience in South America and Mexico indicates that the best serological pair is an ELISA prepared with crude antigens plus another ELISA with recombinant antigens. Molecular biology techniques have shown significant variability and to date they are only useful in particular cases.
Mexico has the National Network of Public Health Laboratories, which has the capacity to carry out the diagnosis in all states of the country and that generally uses crude antigens and the entire parasite as a source of recombinant antigens.

From 2001 to 2017, 33277 samples were processed at the Institute of Diagnosis and Epidemiological Reference of the Directorate General of Epidemiology, Ministry of Health; $48 \%$ (15 878) showed positivity for Chagas disease.

Since the 1990s, important advances have been accomplished in the control of the parasite and the vector in Latin America, specifically in Mexico. Furthermore, the risk of transmission by blood transfusion has decreased due to screening in all blood banks of Latin American countries. ${ }^{7}$

The contribution in channeling patients to the jurisdiction areas by the National Center of Blood Transfusion the state centers has favored the registry of probable cases and prevented transmission by blood transfusion.

\section{Seroprevalence of $T$. Cruzi in blood banks}

Mexico is one of the countries considered to be endemic for Chagas disease by the Pan American Health Organization. There are two types of transmission mechanisms: congenital and urban, with transfusion transmission deriving from the latter. In Mexico, in 2017 there were 596 registered blood banks and, based on the risk factors for seropositivity, an ad hoc questionnaire has been developed for blood donor interview, in addition to showing the triatomine for its recognition. 
Table 2. Trypanosoma cruzi seroprevalence in blood donors in Mexico over an 11-year period

\begin{tabular}{|c|c|c|c|c|}
\hline Year of study & Total blood units studied & Percentage of blood screened for $T$. cruci & Number of cases repeatedly reactive & Prevalence \\
\hline 2007 & 821288 & 54.1 & 3303 & 0.40 \\
\hline 2008 & 1041487 & 64.4 & 4564 & 0.44 \\
\hline 2009 & 1367742 & 82.2 & 5498 & 0.40 \\
\hline 2010 & 1469163 & 86.5 & 5550 & 0.45 \\
\hline 2011 & 1568166 & 88.8 & 6407 & 0.41 \\
\hline 2012 & 1604027 & 92.6 & 7223 & 0.45 \\
\hline 2013 & 1679409 & 97 & 6585 & 0.39 \\
\hline 2014 & 1811090 & 92.8 & 6963 & 0.38 \\
\hline 2015 & 2135081 & 99.3 & 7961 & 0.37 \\
\hline 2016 & 2356387 & 100 & 7482 & 0.32 \\
\hline 2017 & 2402304 & 100 & 8796 & 0.37 \\
\hline Total & 18256144 & - & 70322 & 0.39 Mean \\
\hline
\end{tabular}

Annual summary of total blood units studied, percentage of total blood screened for T. cruzi, number of repeatedly reactive cases and annual prevalence of reactivity against $T$. cruzi 2007-2017. Source: Informe mensual de los bancos de sangre del Sistema de Salud en México. Centro Nacional de la Transfusión Sanguínea. (Prevalence per 100)

Currently, as a result of modifications to the Official Mexican Standard NOM-253-SSA-2012, for the use of human blood and its components for therapeutic purposes, screening for the detection of Chagas disease in blood banks in Mexico is mandatory, with current coverage of $100 \%,{ }^{8}$ when previously it was only done in endemic areas.

In addition to these actions, the reliability of these data was reinforced by programs such as External Quality Control, organized by the National Center of Blood Transfusion, with $88.2 \%$ of participation.

An 11-year study monitored T. Cruzi seroprevalence in Mexican blood banks, which was measured by detecting antibodies against $T$. cruzi in donors. According to the monthly reports submitted to the National Center of Blood Transfusion regarding T. cruzi, between 2007 and 2017, 18256144 units of blood donated in 516 blood banks of the Health System in Mexico were studied, out of which 70322 serology tests were repeatedly reactive (Table 2 ).

During the study period, of the 516 blood banks, 238 were private blood banks (46\%), followed by 100 from the Ministry of Health (19\%), from of the Mexican Institute of Social Security (13\%), 48 from the Institute of Security and Social Services of State Workers (9\%), 27 from state health services (5\%), 11 from Petróleos Mexicanos (3\%), 8 from university hospitals $(2 \%), 6$ from the Red Cross (1.1\%), 3 from the National Ministry of Defense $(0.6 \%), 4$ from the National System for Comprehensive Family Development $(0.8 \%)$ and 3 from the Secretariat of the Navy $(0.6 \%)$.
A decrease in $T$. cruzi seroprevalence of 0.37 was observed in 2017, with regard to 0.40 in 2007 in blood donors.

In the last External Quality Control Program panel, submitted in 2017, 14 false negative results were reported; the blood banks with these results were provided technical advice.

Due to the above, blood banks are regarded as an area of opportunity for early detection and referral of patients to the corresponding health jurisdiction for Chagas disease diagnosis, treatment and follow-up. ${ }^{9}$

The decrease in Chagas disease seroprevalence has been achieved by making improvements in the process of donor selection with an ad hoc questionnaire and showing the triatomine to the donor.

The obtained information has derived in proposals for health policies. The National Center of Blood Transfusion is collaborating in the development of the Manual for diagnosis and treatment of Chagas disease, the contributions of which are intended to establish the donor care flowchart (Fig. 2), screen excluded donors and request local authorities to ratify double-reactive cases, in order to shorten the time to deliver the results.

Finally, given the diversity of triatomine species in Mexico, having a screening test for blood banks with antigens generated in the country is necessary in order to avoid false negative results. ${ }^{11,12}$

Sharing information allows the preparation of multi-sectoral programs with common objectives to the benefit of the Mexican population. 

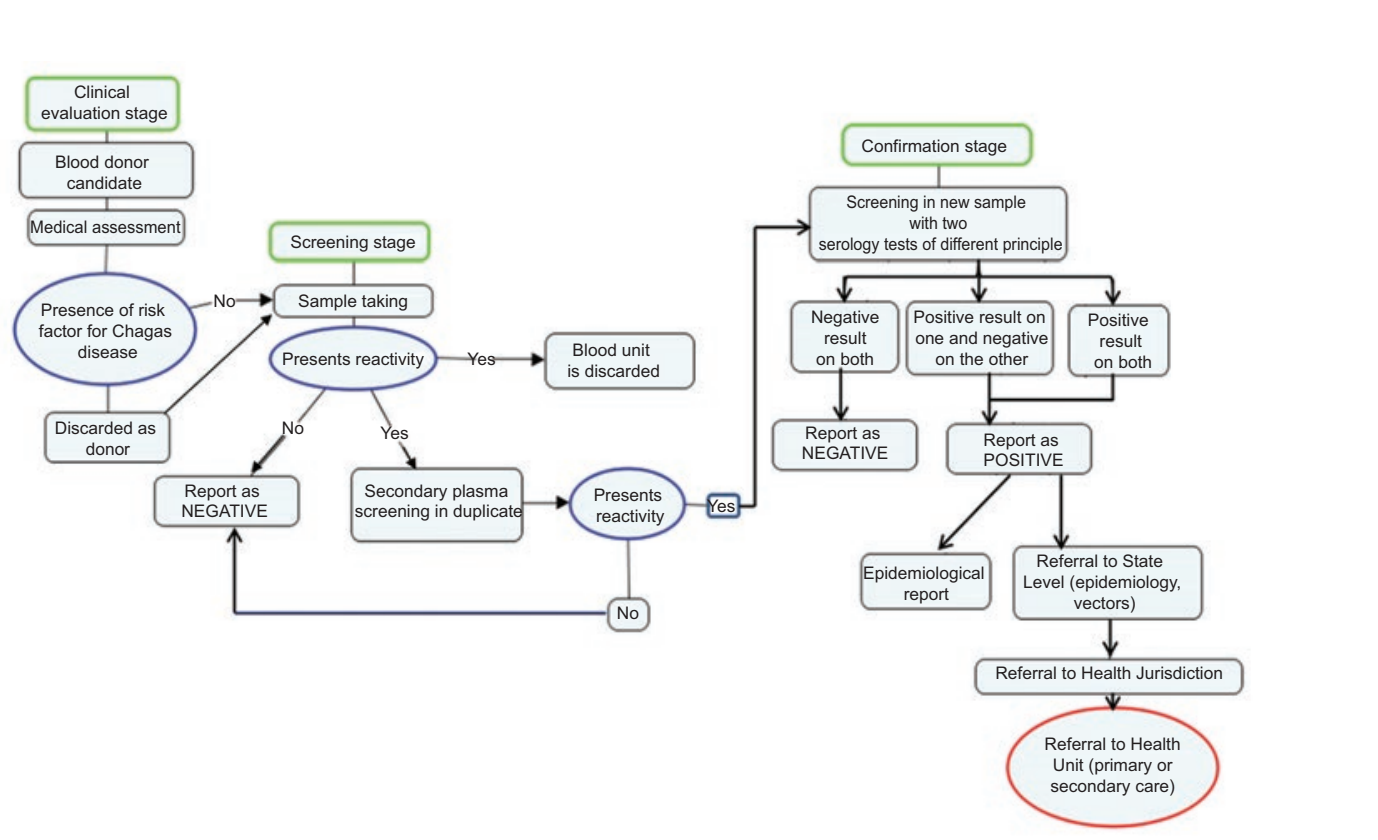

Figure 2. Blood donor care flow chart. Manual for Diagnosis and Treatment of Chagas Disease. Subsecretaría de Prevención y Promoción a la Salud, Centro Nacional de Programas Preventivos y Control de Enfermedades.

\section{Clinical features and treatment of Chagas disease}

To understand the clinical presentation of Chagas disease, it is essential to consider the great ability of $T$. cruzi to invade any cell of the body, except for red blood cells. The cells "targeted" by the parasite include neurons and myocardial and smooth muscle cells. In the former two, it acts simultaneously. Neuronal destruction data are assessed by electrocardiogram, whereas echocardiogram identifies muscle destruction. The association of smooth muscle and neuronal destruction defines the presentation of megachagasic syndromes (esophagus, colon, rarely duodenum, stomach, jejunum, gallbladder, bladder and others).

Initial manifestations of the disease go unnoticed in most acute cases, $5 \%$ have apparent signs and symptoms, and $30 \%$ of these, absence of visible symptoms or signs will evolve to the asymptomatic chronic phase; of said asymptomatic cases, $30 \%$ will develop the chronic clinical presentation with cardiomyopathy or digestive problems.

The acute presentation, the duration of which ranges from 2 to 8 weeks, is characterized by parasitemia; fever with no special characteristics is also identified. Other common clinical signs and symptoms are lymphadenopathies, subcutaneous edema, hepatomegaly, splenomegaly and heart rhythm disorders. In $5 \%$ of patients there is presence of signs that allow to identify the inoculation site: Romana sign, bipalpebral, unilateral, painless edema; inoculation chagoma, indurated, painless lesion, with apparent color changes such as erythema or a violet tone, and that can appear anywhere in the body. Ipsilateral preauricular and submandibular lymph nodes increase in size. Often, there is intense itching. The complex is present for a duration longer than one week.

Some authors indicate that the indeterminate phase or asymptomatic chronic presentation can have a duration longer than 30 years, although, in general, a persistence of 15 to 20 years is considered. Patients at this phase do not exhibit symptoms or signs consistent with the disease and are detected only by epidemiological and serological studies; these patients constitute an important risk for transmission, mainly vector and transfusion-associated, since the parasite persists in the individual.

The main clinical presentation depends on heart compromise. Cardiomyopathy means irreversible visceral involvement. This pathology occurs in most patients as a condition of dilated cardiomyopathy but in occasions it occurs as congestive heart failure, where the patient experiences progressive dyspnea, palpitations, tachycardia, algias; sometimes there may be a single manifestation, such as tachycardia.

The most common electrocardiographic trace in adults of the third or fourth decade of life is incomplete right bundle-branch block, with left anterior hemiblock and ventricular extrasystoles, whereas in younger individuals the usual is incomplete atrioventricular block, which can evolve to complete block. 
Treatment of these patients with cardiomyopathy should be selected with caution because it can lead to greater complications.

Among the megadigestive manifestations, megaesophagus is more common, ${ }^{13}$ which can be diagnosed by radiological imaging; this is how the first case in Mexico, a 24-year patient from the state of Oaxaca with the Triatoma barberi vector, was identified. Spasm of the cardia produces esophageal dilation; symptoms consist mainly of odynophagia or dysphagia, which start with solid foods and subsequently with fluids, halitosis and other symptoms. Dilation can be so severe that internal tissue is lost.

The first case of megacolon described in Mexico, in Oaxaca, was diagnosed due to an episode of constipation of three weeks' duration, with formation of a fecaloma; the only treatment is surgery. ${ }^{14}$ As in the esophagus, spasm occurs in the affected area.

Complications in the acute phase occur in less than 1 $\%$, mainly in children and older adults, and consist of acute cardiomyopathy of high mortality and meningoencephalitis. At the chronic phase, sudden death can occur, which is recorded in 55 to $65 \%$. Other complications include progressive heart failure, thromboembolism and aneurysm at the tip of the heart, which is a pathognomonic sign of this disease observed in Mexico.

The two currently existing treatments only have an effect in the acute phase, since they act on the parasite in blood; at the chronic phase, owing to myocardial destruction, pharmacological treatment has no effect. Benznidazole is a nitroheterocyclic compound that acts on T. cruzi DNA synthesis, mainly on trypomastigotes; it has been used in acute and maternal-fetal infection. Oral nifurtimoxun nitrofuran inhibits the synthesis of trypomastigotes nuclei acids, mainly through the formation of oxygen free radicals, and it is used in acute and chronic cases, where extrasystoles appear to diminish. Experience with both drugs is limited.

Children's Chagas cardiomyopathy, currently described only in Mexico, has been reported in the Veracruz and San Luis Potosí Huasteca regions, where Triatoma dimidiata has been identified, and in Querétaro, where the identified triatomine is Triatoma barberi; these are the only two intra-domiciliary transmission vectors par excellence, the most effective for transmission that exist in the country; Triatoma barberi is a vector that only exists in Mexico. ${ }^{15}$

\section{Prevention and surveillance}

Until 2012, Chagas disease was included among the generic group of "other vector-transmitted diseases" and treatment of cases; nevertheless, recognizing the magnitude and importance of this condition, from 2013 on, the Specific Action Program for Chagas Disease Surveillance, Prevention and Control (2013-2018 Chagas PAE) was created in order to start activities aimed at eliminating transfusion and congenital transmission and at controlling vector-borne transmission. ${ }^{16}$

\section{Components of the 2013-2018 PAE}

\section{Chagas disease}

The 2013-2018 Chagas PAE sets out two fundamental objectives:

1. To control intra-domiciliary vector-borne transmission through risk stratification, housing improvement and chemical control of the vector.

2. To eliminate Chagas congenital and transfusion transmission, strengthening inter-institutional coordination with the areas of Gender Equity and Reproductive Health and with the National Center of Blood Transfusion. ${ }^{16,17}$

\section{Control of intra-domiciliary vector-borne transmission}

The program adopted the "reverse route" strategy, recommended by the Pan American Health Organization/World Health Organization, which consists of applying diagnostic tests to the population at risk and implementing actions for the control of the vector domiciled in areas with positive foci and provide epidemiological follow-up to known cases, to their treatments, to the therapeutic response, and to new cases..$^{18}$ The "traditional route" started with the search for infected vectors to locate foci of chronic disease and was not based on confirmed cases. ${ }^{19,20}$

Currently, vector control is performed twice-yearly in areas with presence of triatomines, an activity that should be reinforced with housing improvement.

Regarding entomological surveillance, 17 states have applied presence-absence surveys, whereby $24.23 \%$ of housing in risk localities have been found to house triatomines.

\section{Elimination of congenital and transfusional transmission}

Prenatal surveillance and screening of pregnant women is carried out in serologically positive areas, and the National Center of Blood Transfusion must be 
certified as a laboratory for Chagas diagnosis to support the work of state public health laboratories and the Institute of Epidemiological Diagnosis and Reference. This surveillance indicates that serological positivity was $2 \%$ in 2017, which has not increased since 2014.

Regarding transfusion-related transmission, actions carried out by the National Center of Blood Transfusion in blood banks and state centers contribute to elimination through regulation of the obligatory nature of blood donor screening. ${ }^{21,22}$

Continuous training in the different levels of care and management of patients on treatment are priorities for this program; in addition, through health jurisdictions, treatment and follow-up of patients who have tested positive for T. cruzi is ensured. In 2017, benznidazole registration by the Federal Commission for Protection against Health Risk was achieved, for considering it the drug of first choice for the treatment of patients with Chagas disease. ${ }^{23,24}$

\section{Perspectives}

Timely detection and early etiological treatment, together with broadening of the coverage, will make successful medical care of patients with Chagas disease possible.

Treatment monitoring, identification of possible adverse effects to anti-Chagas agents and therapeutic results verification with laboratory tests are pharmacovigilance aspects that need to be strengthened. The consolidation of entomological work, vector control and housing quality improvement will allow to control Chagas disease intra-domiciliary transmission, in the same way as surveillance, screening of pregnant women who live in risk areas and blood and organ donor universal screening will make congenital and transfusional transmission elimination possible.

\section{Acknowledgements}

To Universidad Nacional Autónoma de México, for the DGAPA-PAPIIT IN-227816 funding.

\section{References}

1. Guadalupe-Pérez SM, Hernández-Meléndrez E, Rodríguez-Cabrera A. La enfermedad de Chagas como un rezago social en salud. Rev Cubana Salud Pública. 2011:37:59-174. Contents availabe at: http://scielo.sld.cu/ scielo.php?script=sci arttext\&pid=S0864-34662011000100014\&Ing=es

2. Recorrido histórico. [Internet]. Hablamos de Chagas. Contents availabe at: http://www.hablamosdechagas.com.ar/info-chagas/recorrido-historico

3. Uribarruen-Berrueta T. Enfermedad de Chagas. México: Universidad Nacional Autónoma de México/Facultad de Medicina/Departamento de Microbiología y Parasitología. Contents availabe at: http://www.facmed. unam.mx/deptos/microbiologia/parasitologia/trypanosomosis.html
4. World Health Organization. [Sitio web]. Chagas disease (American trypanosomiasis). World Health Organization; 2018. Contents availabe at: http://www.who.int/en/news-room/fact-sheets/detail/chagas-disease-(american-trypanosomiasis)

5. Organización Panamericana de la Salud/Organización Mundial de la Salud. [Sitio web] Mapa de distribución vectorial de Chagas en América Latina 2014. Contents availabe at: https://www.paho.org/hq/dmdocuments/2014/Map-int-trans-vector-chagas.pdf

6. Secretaría de Salud. Norma oficial mexicana NOM-017-SSA2-2012, para la vigilancia epidemiológica. Diario Oficial de la Federación 2013 Feb 19. Contents availabe at: http://dof.gob.mx/nota_detalle.php?codigo $=5288225 \&$ fecha $=19 / 02 / 2013$

7. Instituto de Diagnóstico y Referencia Epidemiológicos. Lineamientos para la vigilancia epidemiológica de Chagas por laboratorio. México: Secretaría de Salud/Dirección General de Epidemiología/Instituto de Diagnóstico y Referencia Epidemiológicos; 2015. Contents availabe at: https://www.gob.mx/cms/uploads/attachment/file/159071/Lineamientos_ para la vigilancia epidemiologica de la enfermedad de chagas.pdf

8. Norma Oficial Mexicana NOM 253-SSA1-2012, para la disposición de sangre humana y sus componentes con fines terapéuticos. México: Diario Oficial de la Federación 2012 Oct 26. Contents availabe at: http:// www.dof.gob.mx/nota detalle.php?codigo $=5275587 \&$ fecha $=26 / 10 / 2012$

9. Manual de diagnóstico de la infección por Trypanosoma cruzi. México 2006.

10. Schmunis GA. La tripanosomiasis americana como problema de salud pública. En: La enfermedad de Chagas y el sistema nervioso. Washington, D. C.: Organización Panamericana de la Salud, Publicación científica núm. 547, 1994. p. 3-31.

11. Ramos-Ligonio A, Ramírez-Sánchez ME, González-Hernández JC, Rosales-Encina JL, López-Monteon A. Prevalencia de anticuerpos contra Trypanosoma cruzi en donadores de sangre del IMSS, Orizaba, Veracruz, México. Salud Publica Mex. 206;48(1):13-21.

12. Salazar-Schettino PM, Bucio-Torres MI, Cabrera-Bravo M, De-Alba-Alvarado MC, Castillo-Saldaña DR, Zenteno-Galindo EA, et al. Enfermedad de Chagas en México. Rev Fac Med UNAM. 2016;59:6-16.

13. Salazar-Schettino PM, Tay J, Bucio MI, De-Haro I, Anzures ME, Flores-Ayala S. Primer caso de megaesófago con serología positiva a Trypanosoma cruzi. Salud Publica Mex. 1984;26:452-455.

14. Tay J, Salazar-Schettino PM, Ontiveros A, Jiménez J, De-Harō, GarcíaYáñez Y, et al. Epidemiologic study of Chagas' disease in a town in Oaxaca, Mexico. Bull Pan Am Health Organ. 1986;20:358-365.

15. Salazar-Schettino PM, Cabrera-Bravo M, Vázquez-Antona $C$, Zenteno E, Alba-Alvarado MC, Torres-Gutiérrez E, et al. Chagas disease in Mexico: report of 14 cases of chagasic cardiomyopathy in children. Tohoku J Exp Med. 2016;240:243-249.

16. Secretaría de Salud. Programa Sectorial de Salud 2013-2018. México: Secretaría de Salud; 2013

17. Secretaría de Salud. Manual de procedimientos estandarizados para la vigilancia epidemiológica de las enfermedades transmitidas por vectores. México: Secretaría de Salud/Subsecretaría de Prevención y Promoción a la Salud/Dirección General Adjunta de Epidemiología; 2017.

18. Organización Panamericana de la Salud. Suministro de sangre para transfusiones en los países del Caribe y de Latinoamérica en 2006 y 2007. Avance desde 2005 del Plan Regional de Seguridad Transfusional. EE. UU.: Organización Panamericana de la Salud; 2009.

19. Organización Panamericana de la Salud. Definición de variables y criterios de riesgos para la caracterización epidemiológica e identificación de áreas prioritarias en el control y vigilancia de la transmisión vectorial de la enfermedad de Chagas. Colombia: Comisión Intergubernamental de la Iniciativa Andina de Control de la Transmisión Vectorial y Transfusional de la Enfermedad de Chagas/Universidad de los Andes/Organización Panamericana de la Salud; 2004.

20. Organización Panamericana de la Salud. Enfermedades infecciosas desatendidas en las Américas: historia de éxito e innovación para llegar a los más necesitados. EE. UU.: Organización Panamericana de la Salud; 2016

21. Silveira AC. Programa regional para el control de la enfermedad de Chagas en América Latina. Comisión Nacional Honoraria de Zoonosis/ Organización Panamericana de la Salud/Banco Interamericano del Desarrollo. Contents availabe at: https://www.paho.org/per/index.php?option=com docman\&view=download\&alias=261-programa-regional-para-control-enfermedad-chagas-america-latina-lineamientos-recomendaciones-tecnicas-politica-publica-para-abordaje-enfermedad-chagas -1 \&category slug=chagas-998\&ltemid $=1031$

22. Guzmán-Bracho C, García-García L, Floriani-Verdugo J, Guerrero-Martínez S, Torres-Cosme M, Ramírez-Melgar C, et al. Riesgo de transmisión de Tripanosoma cruzi por transfusión de sangre en México. Panam Salud Publica. 1998:4:94-98.

23. Organización Panamericana de la Salud. Enfermedad de Chagas en las Américas: una revisión actual de salud pública y su visión para el futuro. Ginebra, Suiza: Organización Panamericana de la Salud; 2018.

24. Organización Panamericana de la Salud. Enfermedades tropicales desatendidas. Ginebra, Suiza: Organización Mundial de la Salud; 2018. Contents availabe at: http://www.who.int/topics/tropical_diseases/qa/faq/es 